\title{
The covariation between carbon and oxygen isotope in Middle Ordovician marine carbonate rock, Ordos Basin, China
}

\author{
YINING LI, WENUI LIU* , XIAOFENG WANG, DONGDONG \\ ZHANG
}

State Key Laboratory of Continental Dynamics, Northwest University, Xi'an, Shaanxi, 710069, China

(*correspondence:whliu@nwu.edu.cn)

Organic-inorganic interactions are often characterized by the altered carbon and oxygen isotopic composition of marine carbonates. In order to figure out the impact of hydrocarbon on the marine carbonate rock during the diagenesis, systematical carbon and oxygen isotope analysis were carried out on drill core carbonate samples, which were selected from Middle Ordovician Majiagou formation in Ordos basin, China. The result shows that the $\delta \mathrm{C}$ and $\delta_{18} \mathrm{O}$ records of carbonate rock in $\mathrm{O}_{1} \mathrm{~m}_{5}$ formation(Upper Majiagou formation) simultaneously shift towards lower values $\left(\mathrm{r}^{2}=0.59\right)$. The $\delta \mathrm{C}$ and $\delta \mathrm{O}$ values of $\mathrm{O}_{1} \mathrm{~m}_{5}$ formation display a wide range between $-10.9 \%$ and $1.8 \%$, between $11.5 \%$ and $-5.4 \%$, respectively(number $=208$ ).

The depositional environment of $\mathrm{O}_{1} \mathrm{~m}_{5}$ formation is arid and hot, making it an important period for the deposition of anhydrite. The previous study shows that the Ordos basin experienced the paleogeotemperature over $220 \mathrm{C}^{\circ}$ in Ordovician[1], which meets the reaction temperature of thermochemical sulfate reduction(TSR). Thus the abundant dissolved $\mathrm{SO}_{4}{ }^{2}$ from seawater is very likely to be reduced by the hydrocarbon in the $\mathrm{O}_{1} \mathrm{~m}_{5}$ formation under high temperature. And the presence of pyrite in this formation can be indentified as the product of TSR. Owing to the TSR, the secondary calcite with organic carbon source was produced, which lead to a lighter $\delta^{3} \mathrm{C}$ value of carbonate $\operatorname{rock}($ value $=-19.9 \%$ o). Meanwhile the oxygen isotope in anhydrite fractionated between water and calcite, resulting in a lighter $\delta: O$ value of secondary calcite[2]. Furthermore, the depleted $\delta \mathrm{O}$ value can also originate from elevated temperatures during TSR. Therefore, we propose that coupled negative excursion in $\delta \mathrm{C}$ and $\delta \mathrm{O}$ values of carbonate rock can be an implication of the occurrence of TSR in $\mathrm{O}_{1} \mathrm{~m}_{\text {s }}$ formation, which can also provide effective evidence for the existence of hydrocarbon in $\mathrm{O}_{1} \mathrm{~m}_{5}$ formation in geological time.

[1] Ren Z L et al(2017), Earth Science Frontiers, 24(3), 137148. [2] R. H. Worden et al(1991), Geochimica et Cosmochimica Acta, 60(20), 3925-3931. 